\title{
Lorenzo Varela: crítica, ironía e humor en Correo Literario (1943-1945)
}

\author{
Ana Martínez García \\ [Recibido, 11 setembro 2019; aceptado, 9 decembro 2019]
}

http://dx.doi.org/10.15304/bgl.55.6264

RESUMO O galego Lorenzo Varela é coñecido pola súa faceta poética tanto en galego como en español e, en menor medida, polo seu labor crítico. Neste traballo recupérase unha vertente menos coñecida, máis irónica e humorística a través da súa participación na revista editada no exilio arxentino Correo Literario (19431945). Nas súas páxinas, os comentarios acedos que escribira noutras publicacións anteriores deron renda solta e, sobre todo, personalidade e orixinalidade a esta revista e á súa sucesora, con enxeñosas directas dirixidas ao mundo da cultura contemporánea, especialmente á España franquista.

Palabras Chave: Correo Literario; Lorenzo Varela; críica; ironía; humor.

ABSTRACT Lorenzo Varela is known for his poetic facet both in Galician and Spanish and less so for his critical reviews. In this study we will discover his more ironic and humorous nature as seen in his participation in the magazine Correo Literario (1943-1945) published during his Argentinian exile His acrid comments written in previous publications gave free rein to this magazine. Furthermore, it was his ingenious blunt words that made this publication and the following one personal and original, directed to the contemporary culture and especially to Franco's Spain.

KEYWORDS: Correo Literario; Lorenzo Varela; criticism; irony; humour.

\section{Introdución: vida e obra de Lorenzo Varela}

A vida de Lorenzo Varela transcorreu entre o exilio e a emigración. Naceu en 1916 nun barco que se dirixía á Habana e poucos meses despois regresou a Galicia. En 1923 trasladouse a Arxentina cos seus pais por un tempo, onde volveu despois da Guerra Civil como desterrado. 
En Lugo iniciou os seus estudos de Bacharelato e a súa andaina política tras unirse a Esquerda Comunista. En Madrid relacionouse con importantes figuras literarias nos máis coñecidos cafés, mentres medraba a súa vertente crítica e literaria tras colaborar en xornais como El Sol (1917-1939) e nas Misións Pedagóxicas. Ao estalar a Guerra Civil Española alistouse como miliciano popular e a súa obra fíxose máis política, con críticas máis audaces, revolucionarias e con función axitadora. Deste xeito rematou participando en publicacións de propaganda política a favor da República como El Mono Azul (1936-1939) ou Abora (1930-1936) (Ferreiro Fente, 2004: 99-101).

A finais de 1937 loitou na fronte, sendo nomeado Comisario Delegado de Brigada. Cando rematou a guerra refuxiouse en Francia, onde sufriu as penurias do campo de Saint Cyprien. Viaxou no mítico barco Sinaia rumbo a México e traballou en importantes proxectos como as revistas Romance (1940-1941) e Taller (1939-1941).

En 1942 estableceuse en Arxentina, onde se dedicou á tradución e á crítica literaria, mentres desenvolvía un importante labor xornalístico. Alí participou nos proxectos editoriais do grupo de exiliados co que se relacionaba até que en 1947, por diferentes problemas políticos, se trasladou a Uruguai. Destacou a súa participación en revistas como De Mar a Mar (1942-1943), que codirixiu xunto a Arturo Serrano Plaja; Correo Literario (1943-1945), que abordamos no presente traballo; e a súa sucesora, Cabalgata (1946-1948); ademais, implicouse coas editoriais que os mesmos compoñentes do equipo redactor destas revistas rexentaron, tales como Nova ou Atlántida ${ }^{1}$. Estas publicacións, como sinalou Emilia de Zulueta (1983), non só tiveron gran repercusión entre os desterrados, senón tamén no contexto cultural arxentino, dando lugar ao que se coñeceu como a "dominante española” pola súa profusión e relevancia.

$\mathrm{Na}$ década de 1950 retornou a Arxentina e aos labores editoriais anteriores, acompañados dunha intensa actividade crítica e literaria. Nestes anos iniciou unha relación con Marika Gerstein, con quen compartiu a súa vida até os seus últimos días, establecido xa na España e na Galicia que tanto estrañou.

1 Para obter máis información sobre a súa participación nos diferentes proxectos dos exiliados, pódese consultar s seguintes referencia: Lorenzo Varela en revistas culturais de México e Bos Aires: Taller, Romance, Letras de México, De Mar a Mar, Correo Literario, Cabalgata, Sur (2005, coords. Ma Antonia Pérez Rodríguez, Xosé López García e Rosa Aneiros Díaz). 
A obra de Varela insírese entre dúas tradicións poéticas: por unha banda, brilla o seu galeguismo e marxismo inicial; por outra, estaba ligado á cultura republicana a través das Misións Pedagóxicas, a Alianza de Intelectuais Antifascistas ou a revista Hora de España (1937-1938). Así, a obra dividiuse en dúas vertentes desenvoltas en linguas distintas. Tamén se relaciona a Varela coa Xeración do 36 polo seu ano de nacemento, á chamada Xeración Nós e ás vangardas galegas polas súas amizades, e á poesía social realista pola súa obra. Mentres tanto, cos seus libros de poemas en castelán, publicados no desterro, facíase eco de tendencias líricas anteriores como o intimismo ou a poesía cívica. Isto provocaba que a súa obra se movese entre a literatura anterior á guerra e as tendencias das novas promocións (Ferreiro Fente: 2004: 133)².

\section{Correo Literario (1943-1945)}

Co subtítulo "Periódico quincenal", o 15 de novembro de 1943 publicáronse en Bos Aires as oito páxinas que compoñían o primeiro número de Correo Literario. Naceu nun bo momento para os desterrados españois, mentres se sucedían as primeiras derrotas do nazismo, e desapareceu co final da Segunda Guerra Mundial, en setembro de 1945, cando os exiliados que a dirixían creron que a vitoria dos Aliados propiciaría o seu regreso a España. O equipo redactor estaba formado por Lorenzo Varela xunto a dous grandes amigos dende a súa mocidade: o pintor Luis Seoane e o poeta Arturo Cuadrado. Xunto a eles tamén estaba como secretario o xixonés Javier Farías.

O seu obxectivo era difundir a cultura hispanoamericana e convidaban a participar a distintos intelectuais seguindo o ronsel americanista desenvolto naqueles anos en numerosos países suramericanos. Para iso artellouse en múltiples seccións con textos literarios, sobre crítica literaria, notas artísticas, escritos de carácter científico médico, novidades musicais, cinematográficas e teatrais.

Lorenzo Varela dirixiu esta publicación xunto a Luis Seoane e a Arturo Cuadrado e o seu labor estivo relacionado coa composición das seccións máis literarias pola experiencia previa coa que contaba. Varela colaborou tamén

2 Para obter unha visión xeral da súa vida e obra poden consultarse, entre outros, os seguintes traballos: Lorenzo Varela. A voz desterrada (Fernando Salgado, 2005); Diccionario Lorenzo Varela (Xosé Gregorio Ferreiro Fente, 2005); As tres mortes de Lorenzo Varela: biografía de un poeta (Antón Lopo, 2005). 
con diversos poemas e críticas literarias e artísticas asinadas co seu nome ou como Felipe Arcos Ruiz. Ademais, como veremos, ocupouse de forma anónima ou baixo pseudónimo das seccións que achegaron maior personalidade á revista, tanto polo seu polémico contido como polo seu modo de abordalo: "Nuevas", a sección dedicada a novidades culturais; "Carta abierta", o editorial da revista; "Premáticas y desahogos", unha colección de acedas e xocosas críticas sobre o contexto cultural arxentino e español e, en múltiples ocasións, a figuras concretas; e "Rehilete en el viento", unha selección de divertidas anécdotas relacionadas con españois de todos os tempos, aínda que tiveron maior presenza os intelectuais e artistas contemporáneos.

\section{As polémicas noticias de "Nuevas"}

A sección "Nuevas" aparecía na páxina inicial para informar sobre noticias históricas e culturais, tanto hispanoamericanas como europeas, deixando un bo espazo ao relacionado con España. Por iso, a Segunda Guerra Mundial foi un dos seus eixos temáticos, especialmente os sucesos ocorridos a intelectuais contrarios ao nazismo e represaliados por iso. Lembraron as vidas dos caídos, frases pronunciadas por quen ansiaba a liberación de París, a pegada que deixaban nos seus países de asilo etc. Entre elas, cun ton amargamente irónico, apareceu: "Franceses o no, todos los que amamos a Francia y la necesitamos, vivimos en el exilio (Julien Green, en La Nación)" ("Nuevas", en Correo Literario, $\mathrm{n}^{\circ}$ 11, 1944: 1).

Aquí sobresaíron outras novidades relacionadas coa actualidade cultural pola súa ironía, onde moitos eloxios encubrían críticas satíricas. Algunhas das figuras apuntadas eran de orixe hispanoamericana, como é posible ver nunha nota á mantenta da cita de Cervantes intercalada nunha exitosa novela pola que o seu autor conseguiu o Premio Nacional, onde os desterrados se verían reflectidos ao crear da nada os seus múltiples proxectos para sobrevivir dende a distancia: "Esto de el hambre; como decía Cervantes; tal vez hace arrojar a los ingenios a cosas que no están en el mapa'. Aleccionadora cita de José Revueltas en su admirable novela El luto bumano" ("Nuevas", en Correo Literario, $\left.\mathrm{n}^{\mathrm{o}} 3,1943: 1\right)$.

No oitavo número ("Premáticas y desahogos", en Correo Literario, n 8 , 1944: 2) destacou a noticia dun arxentino que descoñecía moitas cousas: 
"Madrazo es más cerrado de colorido que Winterhalter, y hasta diría que más alemán que él” (Martín de Ondarrubia, en La Nación). Este desconocido "Don Martín" debe confundir la pintura de Madrazo con el petróleo norteamericano que siempre es más alemán que español.

Estas notas resultaban comedidas se as comparamos con aquelas dedicadas a figuras españolas, que eran máis xocosas e ferintes. Dirixíanse a figuras relacionadas co réxime franquista e son as que lle conferiron orixinalidade á sección. Xurdiron no segundo número con tres agudas novas. A primeira centrábase en Gregorio Marañón, un médico que experimentou durante varios anos o desterro e que regresou a España adaptándose ás condicións políticas imperantes. Sobre esta actitude fala a noticia publicada na sección "Nuevas" do número 2 de Correo Literario (1943: 1) remitíndose a anos antes da guerra:

En 1932 apareció un libro cuyas páginas estaban todas en blanco. Se titulaba: Discursos de Marañón en el Parlamento. Se agotó la edición. Ahora la primera meditación del Dr. Gregorio dende Toledo comienza: "Nadie sabe al escribir un libro lo que este libro dirá a sus lectores cuando, unos años después, corra por el mundo".

$\mathrm{Na}$ mesma liña apareceu outra nota para burlarse dun escritor español afincado en España, ao que ridiculizaron tras a obtención dun galardón: "Eduardo Marquina ha sido agraciado y le será impuesta la gran cruz de Alfonso el Sabio. ¡Bueno, o malo hubiese sido que Alfonso el Sabio tuviese que sobrellevar la gran cruz de Eduardo Marquina!" ("Nuevas", en Correo Literario, $\mathrm{n}^{\circ}$ 2, 1943: 1).

Por último, quizais a máis simpática de todas viraba ao redor de Salvador Dalí e o seu nome, cun apelido que era perfecto para describir a súa personalidade ("Nuevas", en Correo Literario, n 2, 1943: 1):

V. Toutjean, vecino de Oakland, California, con acento puritano solicita de una revista americana que le aclare el significado del nombre de Salvador Dalí. Y "Esquire" contesta: Salvador Dalí fue bautizado correctamente -en turco "Dalî" significa "loco".

No sétimo número destacaron estas palabras do Conde de Romanones ("Premáticas y desahogos", en Correo Literario, no 7, 1944: 2), seguidas dun acedo comentario: 
"Soy un admirador tan férvido del Renacimiento, y sobre todo del Renacimiento de Italia, que si yo hubiera podido designar el lugar de mi nacimiento sin vacilar dijera Florencia y en el siglo XVI". (Última declaración de Romanones). Y lo que también ha ganado España y el siglo XX.

$\mathrm{Na}$ novena entrega sobresaíron varias notas asolagadas pola mesma tinguidura maliciosa, á mantenta de Unamuno e a España Franquista ("Premáticas y desahogos", en Correo Literario, n 9, 1944: 2):

Una revista de la España actual afirma "que las obras de Don Miguel de Unamuno son peligrosas para los lectores", pensamiento reforzado por el azul Julián Marías que al ilustre escritor vasco no le concede crédito ni como filósofo siquiera. ¡Pues nada, se acabó Unamuno! (Letras de México)

En una edición española de "La Tía Tula" figura la siguiente errata: "nuestra España inmoral cuya es empresa”. Inmoral por inmortal. Ya Don Miguel cita en su lucha con los tipógrafos presintiendo otra España alejada de su pensamiento.

No número doce acordáronse do poeta Gerardo Diego, gran amigo de moitas das figuras esenciais do desterro e que permaneceu na península tras a guerra: "Recuerdo ahora una tarde de tiempos más felices que los presen38 tes' (Gerardo Diego en 'Paseos de Jovellanos'). A estos tiempos presentes ha contribuido activamente el joven poeta" ("Nuevas", en Correo Literario, $\mathrm{n}^{\circ}$ 12, 1944: 2).

$\mathrm{Na}$ mesma liña, atacando a quen quedou en España e a súa produción cultural, apareceron varias noticias no número dezaseis. A primeira utilizaba o sarcasmo para burlarse do estado da escena peninsular naquel momento, afectada pola morte ou o exilio dos mellores dramaturgos españois: "Aquí en España la temporada teatral sigue igualmente monótona en su desmayo y en su insignificancia' (Del testamento de Joaquín Álvarez Quintero)" ("Nuevas", en Correo Literario, no 16, 1944: 2).

Dado que a Segunda Guerra Mundial e o seu próximo final tomaron protagonismo, estas acedas novidades case desapareceron desta sección para sumarse a outras con tinguiduras irónicas. No número trinta e sete volveron publicarse dúas: unha brillou pola gravidade da cita en relación a España e a súa política; a outra pola súa relación coa ideoloxía, actitude e participación dalgunhas figuras do ambiente cultural durante a guerra ("Nuevas", en Correo Literario, $\mathrm{n}^{\circ} 37,1945$ : 1): 
Knut Hansum, colaboracionista, se enfermó al ser informado de la rendición alemana.

"La guerra empezó en España. Allí los monstruos nacionalsocialistas se ejercitaron para la guerra." Thomas Mann, en “Oíd, Alemanes”.

\section{“Carta abierta”, a sección editorial de Correo Literario}

Na segunda páxina de Correo Literario incluíuse "Carta abierta”, a sección editorial da revista, case sempre publicada de forma anónima, menos cando a asinaba "Hermes", pseudónimo que revelou Luís Seoane. Fíxoo no libro de homenaxe póstuma a Lorenzo Varela (Seoane, 1979: 12), onde confesou que era a súa pluma a que asinaba esta e outras seccións nas que atopamos máis comentarios irónicos e mordaces.

Esta carta mostraba un gran apoio á Francia demócrata, temas de actualidade como a indignación ante o esquecemento que sufrían algúns exiliados e hispanoamericanos (entre os que tamén se atopaban os refuxiados e sobreviventes da guerra), comentarios que se facían eco doutros aparecidos en revistas coetáneas como críticas contra personalidades literarias protexidas polo Franquismo, noticias de actualidade política etc.

Outra das liñas temáticas era a literatura e a cultura, incluíndo diálogos con outras publicacións. Así se reflectía no segundo número da publicación, onde se conversou coa revista El Hijo Pródigo, publicada en México con gran participación de españois exiliados. Dende Correo Literario falábase do seu editorial, sempre titulado "Imaginación y Realidad", onde se poñía de relevo a problemática que a defensa da imaxinación producía, dado que nalgúns círculos esta actitude inspiraba repulsa. A este respecto defendíase a necesidade histórica de novelar o presente e de sospeitar de "muchos 'imaginativos' demasiado avisados o extremadamente alelados y desvariantes, [que] han contribuido a ello, ya sea, en efecto, por su 'cabeza llena de humo' o por su 'boca llena de mentiras" ("Carta abierta", en Correo Literario, n 2, 1943: 2). A pesar diso, non esquecían que o traballo de quen loitaba pola imaxinación era o daqueles que cimentaban a cultura do pobo.

Número a número falaban sobre outras publicacións coetáneas como o xornal bonaerense La Nación e revistas como Sur ou Cuadernos Americanos 
e as súas relacións, clubs de lectura, concursos literarios... Non obstante, centrábanse en mostrar como a literatura e o compromiso se unían. Así se pode ver na carta do cuarto número ("Carta abierta", en Correo Literario, $\mathrm{n}^{\circ} 4$, 1944: 2), cun escrito en defensa da literatura comprometida que eles mesmos cultivaban:

Nadie ni nada podrá separarnos de una idea fija, obstinada, voluntariosa: la de trabajar para poner nuestra parte en la contienda. No podemos repartir el sacrificio de Europa y de Asia, pero al menos queremos pedir nuestra porción en la fatiga, nuestro objetivo en el esfuerzo. Sin que cuenten los desvelos, las atormentadas horas de vigilia, la renuncia a las alegrías de las fiestas. Sin que cuente el ya agitado deseo de que la victoria se gane mañana mismo, ahora mismo. Sin que cuente ese dolor que en el alma y en la sangre se nos va volviendo amargo, ese dolor ante el drama cuya lejanía geográfica es tan solo un motivo más para intensificar la congoja que nos causa.

No número vinte apareceu un sentido texto dedicado aos escritores que loitaban dende Francia polos ideais que defendían os redactores desta revista. Como mostra do seu apoio, dende Arxentina enviaban exemplares de Correo Literario para que visen o seu traballo, as súas ganas de loitar, de crer...

Han salido los primeros números de CORREO LITERARIO para Francia. Pronto estará en París nuestro periódico, llevando esta "Carta Abierta" escrita con la emoción del momento y con el mensaje de nuestra actitud, ya que la actitud de nuestros amigos, huele a la insobornable flor de la lealtad.

Hace cuatro años que vínculos materiales nos tenían alejados de los escritores franceses y de los escritores españoles residentes en tierra francesa. Este vínculo material no eludía el conocimiento de su actitud espiritual, manera de usar la inteligencia, que muchas veces fue ejemplo y ánimo para nosotros los afortunados en llegar a las Américas. Aquellos hombres, en el corazón del peligro, peligro de muerte más que de cárcel, tuvieron su voz para el pueblo y sus cuerpos para la lucha por la Libertad.

Sabemos, amigos, de vuestras largas noches, de vuestros manuscritos, de vuestro valor, del tesoro de un poema en una pared o del manifiesto escrito en el silencio sin silencio.

Mas vosotros, camaradas de la tormenta, quizá no tuvieseis tiempo de escuchar nuestra razón de existir, de escribir, de pensar. Defender la vida de un campesino o elevar la moral de un pueblo, tenían más urgencia que nuestro regalo o nuestra ayuda. Los poetas de España ya lo habían aprendido con la sangre y con el sacrificio.

Ahora ya el horizonte está aclarado para recibir nuestra obra, nuestra obra hecha con vuestro mismo desvelo, con vuestro mismo amor, con vuestro mismo 
entusiasmo leal. Somos de la misma carne y del mismo acero, forjado en una memorable jornada de Madrid, en la Defensa por la Cultura.

Aquí estamos hoy como ayer y como mañana. Recibiréis nuestra obra con nuestros nombres. Los vuestros los llevamos tan a lo vivo, tan a flor de piel, que tenemos vergüenza por no haber podido estar en las más duras jornadas a vuestro lado, para conquistar lo más sagrado, lo más grande, lo más noble: la patria invadida.

Pero a nosotros, a aquellos amigos españoles, que han encontrado otros muchos y leales amigos en América, aún les falta otra jornada por ganar: Madrid ( “Carta abierta”, en Correo Literario, n 20, 1944: 2)

A sección do número vinte e oito denunciou as insidias que levaban a cabo moitas editoriais, comentando o sucedido na Cámara Arxentina do Libro. Alí acordouse celebrar unha feira do libro arxentino á que estaba convidada a comunidade editorial española. Os desterrados, os creadores de Correo Literario e todos os contrarios ao fascismo e nazismo recibiron esta invitación con receo. Segundo a redacción desta revista, a través da península chegarían a América

[...] los libros de las editoriales nazis en España, ofrecidos en un castellano lo más correcto posible y hasta con apellidos de bien probada al parecer ascendencia española. Y quizás, coronando tan enmascarada embajada, en compañía los tales libros de alguno o algunos de los más funestos autores de la literatura española, con su camisa azul y su correaje de pistolero literario ( "Carta abierta", en Correo Literario, $\mathrm{n}^{\circ}$ 28, 1945: 2).

A sección "Nuevas", facía referencia a múltiples figuras españolas afincadas na península. Estes personaxes ocuparon outras seccións, entre elas "Carta abierta", onde se ofreceron noticias, burlas ou críticas sobre España e figuras relacionadas co Réxime Franquista. Tal foi o caso do número quinto, a partir do cal a sección apareceu asinada de maneira ocasional baixo o pseudónimo "Hermes". Nel incluíuse un xocoso texto que, ao fío do Qü̈ote, atacaba frontalmente a Giménez Caballero e outros como el:

En un lugar de Europa, de cuyo nombre no quiero acordarme, se ha iniciado una amplia campaña contra Don Quijote de la Mancha. A toque de corneta se han lanzado sobre él los bárbaros de choque, mientras las reservas se instruyen y se preparan a entrar en el fuego inquisidor. A la cabeza de las mesnadas se ha puesto Giménez Caballero, primer bastardo de las letras de idioma cervantino, segundón condecorado por todos los diablos del resentimiento, y que, de tener linaje, es seguro que los infantes de Carrión, aquellos en quienes Machado el grande vio el germen del señoritismo, con sus fundadores más preciados. Y ya 
encontró su Robleda de Corpes literaria, pues la obra mayor y más pura de las letras españolas, una de las creaciones estelares de la Europa cristiana fue puesta a su merced para que sacie su mezquina pasión.

Junto a Giménez Caballero han puesto a otros nueve notarios menos notorios para que levanten el acta de defunción del Quijote. ¡Con qué regüeldos pondrán esos fúnebres señores estas horribles letras! Aquí yace la libertad, la justicia, el valor, el sueño cristiano de los hombres! ¡Aquí yace la honra del pensamiento español! Y luego irán los diez a ver cómo vuela, pateada, la primera edición del hidalgo.

Esta es la gran revancha de los Avellanedas, la entronización de los falsos quijotes, el triunfo fugaz de los Carriones, la suprema traición que al espíritu universal hace Giménez Caballero, el pobre, el pequeño, el feo Giménez Caballero, enemigo personal de Don Quijote de la Mancha porque se sintió humillado con su simple lectura. ¡Buenos motivos tendría!

Dende ahora también tenemos nosotros un motivo más para amar a Nuestro Señor Don Quijote, para venerar al héroe de nuestro espíritu, a nuestro Don Miguel de Cervantes Saavedra. Gracias a este despropósito, el Quijote se nos hace aún más hispano, más rico de altísimas intenciones, más gracioso y burlón, más superior. En Sancho hemos de encontrar las palabras socarronas de la loca cordura que nos hará mirar piadosamente la encanijada figura de Giménez, la pobre aunque mortal loquería que hay detrás de Giménez y de su jauría letrada. Dende ahora el Quijote tiene ese hueso de realidad que a veces le faltaba y lo hemos de ver de verdad luchando contra tamaños malandrines y follones, contra tales torpes remendones de hechizos y de encantamientos. Creíamos que era solo nuestro gran muerto, el muerto glorioso que da luz y sentido y honor a los vivos. Pero lo han vuelto a poner en pie para que queme nuevamente a los falsos libros de caballerías, de los Giménez y de los Pemanes y de los Góngoras, y para que arremeta contra los truhanes que lo inventaron.

Todo lo que tenía de malo el Quijote era que estos señores lo elogiaban, hablaban en su nombre, se consideraban yernos o primos segundos de él; ahora ya estamos completamente libres de esa triste obsesión, ya vemos que no hay en su sangre una sola mancha, y que quienes ahora lo niegan en realidad nunca lo han reconocido antes. Toda la pesadez que tenían las ediciones últimas del Quijote le venía de ese lado: los prólogos y acotaciones y epílogos con que lo estropeaban los académicos que hoy lo expulsan de las universidades y de las escuelas. Quizás antes obedecieran a un plan sórdido y aquella pedrea retórica que metían junto a la palabra viva de Cervantes era una manera de encarcelarnos el Quijote para que no fuéramos a verlo, para hacer que su grandeza no se contagiase a las gentes. A las gentes que son gente. Alegrémonos, pues, de que con su grosería nos le liberen, nos lo dejen sin malas y subrepticias cartas de presentación, nos lo devuelvan íntegro y solo, sin malas compañías. Y aprestémonos a preparar el gran homenaje de sus fieles, ese leal banquete de duelos y quebrantos que merece su brazo valeroso (Hermes, "Carta abierta", en Correo Literario, $\mathrm{n}^{\circ}$ 5, 1944: 2). 
No número sétimo criticouse un texto dun médico e escritor relacionado coa política española, ademais de académico, tras quen probablemente se escondía Gregorio Marañón que, logo de mostrarse contrario a certas actitudes dos gobernantes de esquerda da Segunda República, espertou sentimentos dispares. Reproducimos esta nota pola importancia que se dá ás novidades recibidas dende España e a relevancia do artigo comentado, onde se homenaxeaba a Antonio Machado:

Hemos leído un artículo sorprendente, tanto por la firma que lleva al pie, como por el lugar en que se firma. Su autor, tan hábil en la medicina como en la literatura, y en las dos cosas igualmente audaz, pero más hábil y audaz aún en la política, en esa cosa mal llamada política que huele dende lejos a mascarada fúnebre, afirma dende Madrid que los poetas desterrados tienen razón, que el tiempo habrá de dársela. Por estos días se cumple el destierro de la poesía contemporánea española, con la venerable figura de don Antonio Machado a la cabeza. ¿Habrá escrito el dolor su artículo para conmemorar el aniversario? La actitud enmarañada del mismo durante los acontecimientos de los últimos años, y hasta ayer mismo, nos hace dudar de su intención conmemorativa. Pues es propio de médicos prudentes el curarse en salud, aunque esta flaquee en virtud de lo contundente que resulta el franco éxito militar de las tropas alidadas. ¿Querrá hacer el doctor a tiempo las curas propias del médico que quiere curar las úlceras de su honra? Ya sabremos algún día cercano, cualquier día de estos en que nos levantemos y el mundo sea algo mejor que el actual para los desterrados, los verdaderos propósitos que encierra el artículo del doctor no desterrado. Pero estamos de acuerdo con él en que los poetas desterrados, dende antes de Séneca, tuvieron siempre razón, esa razón digna que obra y es amor y no "buenas razones", como las que tan tardíamente y sin previo Jordán atrapó el doctor español. Los tiranos pierden a la larga, es la tesis del ex republicano, ahora académico. La poesía y el dolor ganan al final de la partida. Dende el destierro una voz sola puede más que el coro de ranas. No se equivoca el doctor: volverán los desterrados quizás a tiempo de mirarle a la cara para ver la marca que tan empeñosamente conquistó.

Pero nada de esto es lo importante hoy, ahora, al comentar este artículo del ilustre académico español: lo más importante es ver cómo la dignidad se pierde en un suspiro y se empaña más definitivamente todavía en otro. Lo importante es decirle a esta especie de nuevos amigos, que se apresuran a tender la mano, como si la mano del desterrado se pudiera amoldar a semejantes cordialidades. Con los tiranos pierden la partida sus juglares, sus parteros, sus genízaros. Pierden los que no han sabido ganarse el destierro, cuando tan fácil era. Los que contribuyeron a ese destierro de la poesía, pagarán sin duda su tributo, su rescate, que por cierto no puede constar tan solo de un tímido artículo piadoso, en el que se ponga toda la capacidad consoladora a que está acostumbrado el médico de la cama de ciertas personitas ("Carta abierta", en Correo Literario, ${ }^{\circ}$ 7, 1944: 2). 
No noveno número (1944) rememoráronse as exposicións internacionais que se celebraban antes da Guerra Civil e da Segunda Guerra Mundial. Dadas as circunstancias político-sociais do planeta, comentábase que España, grazas a Eugenio D'Ors, ideara o modo de celebralas naquel momento convidando os pintores españois non desterrados e, para ofrecer o toque internacional, os españois de Filipinas que se atopaban sometidos ao imperio xaponés.

Destacou no seu número vinte e catro (1944) un balance da súa traxectoria tras cumprirse un ano da publicación. Crían cumprir os seus propósitos, a pesar das trabas e críticas recibidas por non tomar partido contra determinados intelectuais e por non establecerse como un xornal de grupo, senón como un órgano de información independente.

En canto á súa difusión, a "Carta abierta” declaraba que, a pesar da falta de medios, Correo Literario distribuíase polo continente americano. Para iso, nomeaban ás empresas que estaban tras eles: a Imprenta López, de tinguiduras socialistas, a quen lle deran publicidade nalgunha ocasión; a Editorial Poseidón, dirixida polo exiliado catalán Joan Merlí; a Editorial Losada, do emigrado español Gonzalo Losada, que acollía a numerosos traballadores exiliados; a Editorial Nova, de Seoane e Cuadrado, dous dos directores da revista, na que traballaban moitos dos seus colaboradores; e a afamada librería O Ateneo de Bos Aires.

O número vinte e cinco (1944: 2) estaba moi ligado a unha das ideas expostas no número anterior. Denunciaba que poucas revistas ofrecían "una crítica libre de presiones de cualquier índole". Por iso afirmaban que dende Correo Literario continuaríanse publicando recensións ecuánimes que axudasen ao lector para decidir as súas próximas lecturas e, sobre todo, que ensinasen aos escritores a aprender da crítica recibida.

No número trinta e oito (1945) apareceu un novo balance da súa actividade durante case tres anos. Como non se incluíu o editorial no seu último número, este escrito foi o máis próximo a unha despedida. Nas súas palabras expresábase o convencemento de que colaboraran na loita a favor da cultura, para o que contaron con voces de gran relevancia no continente. Ademais, poñíase de relevo un dos problemas que experimentaron que correspondía coa loita contra os detractores que tentaron pecharlles a revista: 
En aquellos días lejanos de casi una perfecta soledad fuimos torpemente atacados por los periódicos nazis, que pedían nuestra expulsión y nuestra eliminación. No combatían nuestra idea, solamente les molestaba la función del intelectual ante la soberanía del pueblo. Los que nos atacaron -hoy muertos-, respondían al trágico grito de Millán de Astray de "Muera la inteligencia" ( “Carta abierta”, en Correo Literario, n 38, 1945: 2).

Ademais, anunciaban o seu paso a unha periodicidade mensual, o cal non implicaría unha falta de novidade para o lector. Este cambio, segundo afirmaron, non lles deixaría un baleiro de mes a mes nas súas lecturas, porque durante o seu longo proceso, os seu case tres anos de vida en solitario, os esforzos realizados animaron a outros intelectuais a acompañalos na súa loita a favor da cultura en tempos de guerra con novas empresas editoriais.

No número corenta, o último da revista, non apareceu o editorial, deixando así aos lectores sen información algunha sobre o seu cesamento.

\section{"Premáticas y desahogos"}

Esta sección, xunto a "Rehilete en el viento", deulle un carácter distinto e propio á revista, pois noutras publicacións do desterro non xurdiron escritos con tinguiduras satíricas como os de Correo Literario. Durante os primeiros doce números facíase fincapé en cuestións relativas a intelectuais da súa mesma nacionalidade, con quen o asinante das sátiras compartira vivencias dun pasado que desembocou nunha guerra.

Número a número, sempre na segunda páxina, apareceron unhas polémicas sentenzas escritas con acidez que puideron dar pé a grandes debates entre os seus lectores, sobre todo españois. Eran pensamentos dun ton crítico e irónico arredor do mundo literario, artístico, teatral, cinematográfico e editorial, destinados a polemizar ao redor de actitudes, sucesos ou personalidades que protagonizaran algunha estrambótica novidade.

En tres ocasións apareceu asinada baixo o pseudónimo "Cojuelo", tras quen Luis Seoane (1979: 12) confesou que se atopaba Varela. A súa elección, como indicaba Daniel Salgado (2005: 53), proviña do gusto do galego pola literatura do barroco, concretamente El diablo Cojuelo de Luis Vélez de Guevara. Nestas páxinas Varela pretendía continuar o ton desenfadado, crítico e picaresco do seu modelo. 
Entre estas reflexións, como no caso de "Nuevas" e mesmo de "Carta abierta", destacaron en número as referencias aos temas máis abordados na revista e, por suposto, a todo o relacionado coa literatura e con figuras españolas.

Eran pensamentos dispares que podemos agrupar polo seu contido en diversos bloques. En primeiro lugar, atopamos os centrados en autores hispanoamericanos que comezaron con Martín Luis Guzmán, afamado novelista mexicano do que se describían as súas técnicas de persuasión para o éxito. Varela tivera con el diversos problemas cando estivo á fronte da redacción da revista Romance (1940-1941), pois tratábase dun proxecto ideado por Lorenzo Varela e Antonio Sánchez Barbudo ao que se sumaron outros desterrados como Juan Gil-Albert e Juan Rejano. A pesar diso, durante a edición da revista e por decisión editorial, impúxose como director a Guzmán, o que supuxo o abandono do equipo redactor inicial. Ademais, no medio desta historia, apareceu o poeta español exiliado Juan José Domenchina, quen publicou nas páxinas centrais de Romance -tras o cesamento do galego- unha composición satírica ligada a libro de poemas Elexías españolas de Varela (Daniel Salgado, 2005 e Fernando Salgado, 2005). Así, a sección "Premáticas y desahogos" (Correo Literario, $n^{\circ}$ 4, 1944: 2) recolleu as seguintes palabras: "El estilo de Martín Luis Guzmán, es de cazador: apunta, hace fuego, y regresa a la oficina con el prójimo en el zurrón”.

Os asiduos colaboradores tamén tiveron lugar na sección, como foi o caso de Octavio Paz e Nalé Roxlo. A primeira "premática” estaba centrada nunha errata do poeta chileno; e a segunda desexaba defender ao seu colaborador das críticas.

Gracias a una aguda observación anónima hasta ahora, de Octavio Paz, sabemos que hay escritores que son escritorios (Cojuelo, "Premáticas y desahogos", Correo Literario, ${ }^{\circ} 5,1944: 2$ ).

"Una viuda difícil" despertó los malévolos comentarios de muchos viudos de las artes, que, en círculos de insatisfechos, criticaron los tocados de la dama. A Conrado Nalé Roxlo no le perdona ninguno de estos dómines que no haya hecho una estupidez. A las gentes del oficio les molesta que se les dé el tono. Nunca perdonan la calidad, a no ser en los clásicos o en los franceses. Y eso porque tanto en un caso como en otro, nadie les pide ni les da consulta. Los enemigos de la viuda difícil, lo son solo por lo difícil, nunca por lo viudos pobres solterones bataclaneros, a los que la viuda alegre concede su literatura fácil, al alcance de las entendederas más desprovistas ("Premáticas y desahogos", en Correo Literario, $\mathrm{n}^{\circ}$ 10, 1944: 2). 
Así mesmo, un descoñecido Luis de Góngora de orixe suramericana deu moito xogo. Asinaba as súas "pobres" composicións sen pretensión de distinguirse de Luis de Góngora e Argote, asignándose incluso un "don” do que se burlaba Varela ("Premáticas y desahogos", en Correo Literario, n 6, 1944: 2):

Hay un señor que se llama Don Luis de Góngora y que no es Góngora. Ni siquiera es el gongorilla de que hablaba Quevedo. Sin embargo se llama así: Don Luis de Góngora. Y cuando hace solicitudes dice: El que subscribe Don Luis de Góngora... Y cuando publica sus versos -pues Don Luis de Góngora es poeta- pone después del título: por Don Luis de Góngora.

Mientras, Góngora, en el purgatorio, confiesa que lo que más le molesta es que su apellido viva de esa manera terrible, atroz, espantosa.

Xunto a estes intelectuais, outros de carácter internacional foron o obxectivo do seu enxeño. Entre as figuras nomeadas chamaba a atención Ernest Hemingway, quen se relacionou con algúns exiliados españois como Varela, polo que coñecía ben a súa personalidade; por outra parte, tamén estaba Bernard Shaw, que foi diana de diversas elucubracións, tanto nesta revista como na que editaron tras o seu cesamento. Vexamos os exemplos máis destacados:

Mientras la un día devoradora de temas oníricos lee a Lin Yutang, hoy, día de difuntos, llevemos un manojo de fieles margaritas a la tumba de aquel monstruo terrible que se llamaba surrealismo.

Ernest Hemingway es un escritor que tiene la capacidad adquisitiva de Henry Ford, la audacia de Al Capone y la inteligencia que exige la Metro-GoldwynMayer.

Decía Bernard Shaw, después de un viaje a Roma, que había allí tanto enardecimiento religioso, que hasta se advertía en los clérigos.

Y a propósito del anciano genial dramaturgo, he aquí la última definición que sobre él nos dio el bohemio: "Bernard Shaw es una mezcla de Matusalén y "enfant terrible" ("Premáticas y desahogos", Correo Literario, n 1, 1943: 2).

No hay ninguna razón en contra para proponer a André Breton como candidato al Premio Nobel. El surrealismo, como la dinamita, necesita la consagración de su arrepentimiento ("Premáticas y desahogos", Correo Literario, no 4, 1944: 2). ${ }^{3}$

A Giradoux -que en paz descanse- lo mató una palabra: la palabra hielo.

El gesto de Bernard Shaw reside en el rabillo del ojo (Cojuelo, "Premáticas y desahogos", Correo Literario, no 7, 1944: 2).

3 Salgado (2005) xustifica a mención do movemento surrealista coas tentativas que tivo Varela naqueles anos de crear unha poética próxima ao neorromanticismo. 
Novelas como El hombrecillo de los gansos debían ser prohibidas por el estado perfecto a que todos aspiramos, pues, como el monte Everest, nunca pueden ser escaladas sin que el atrevido se apunte, o se hunda entre tanto y tanto ventisquero. En todo caso, sólo se permitiría su arriesgada y peligrosa lectura a un tipo de hombre que, como el Hombre Montaña, tiene merecido, por derecho natural, ese cruel castigo. Si se llegara a esa perfección soñada, no le notaríamos a ciertas gentes en la cara ese resplandor fatigoso que denuncia al lector enfermo, loco, que mantiene en secreto, que reserva para sí el misterio de haber leído íntegramente esa pampa enorme de densa narración. Por nuestra parte, huyamos, como del diablo, de semejante sopera descomunal ("Premáticas y desahogos", Correo Literario, $\mathrm{n}^{\circ}$ 11, 1944: 2).

O cinema e o teatro eran artes que formaban parte da sección "Retablo" e tiveron eco en "Premáticas y desahogos". Lembremos que moitos desterrados traballaron en diversas actividades relacionadas co cinema, algunhas delas promocionadas na revista. Bo exemplo diso foi o guión que fixeron María Teresa León e Rafael Alberti de La dama duende, ou as escenografías creadas por Gori Muñoz.

Apenas se ofreceron críticas directas a figuras do mundo cinematográfico ou teatral, pero si bromas ou chistes que viraban ao redor das súas actitudes, imbuídas en moitas ocasións polas ansias de éxito.

Esas gentes que van al cine para olvidarse de la fea realidad, a veces deberían suicidarse a la salida ("Premáticas y desahogos", Correo Literario, no 6, 1944: 2).

El del teatro no es un problema, es un empresario ("Premáticas y desahogos", Correo Literario, ${ }^{\circ}$ 6, 1944: 2).

A última hora hemos perdido las esperanzas que teníamos puestas en los directores franceses que fueron a caer a Hollywood. Parece como si a cada uno de ellos les hubieran cubierto la intuición de antes con esa definitiva parafina de ahora, y hasta en las imágenes antes limpias se enmaraña el chicle del éxito, el gran panqueque del triunfo (Cojuelo, "Premáticas y desahogos", Correo Literario, $\left.\mathrm{n}^{\mathrm{o}} 7,1944: 2\right)$.

"El diablo dijo no", es una película agradable, no sólo porque las únicas piernas femeninas feas que intentan lucirse en la película son mandadas sin vacilación al infierno, sino también porque nos muestra el aspecto generoso de Belcebú. Este, al rechazar un posible huésped de las llamas, realiza una acción digna del más sentimental y honesto de los hombres angélicos. Si el diablo fuese editor, el huésped estaría quemándose ("Premáticas y desahogos", Correo Literario, no 9, 1944: 2).

Cuando una revista se llama Cine no debe admitir en sus páginas a ningún malo que escriba con los sonidos de "La vache qui rit". Para hacer de malo no basta 
haberse alimentado con jugo de cactus, como se supone que hacen los coyotes huérfanos, es preciso, además, superar la ternura de ese líquido vegetal y no pretender llegar a ser el bicho que picó al tren. Es decir, hace falta tener buen humor.

De la temporada de teatro lo mejor son los recuerdos ("Premáticas y desahogos", Correo Literario, n 10, 1944: 2).

Cree la primera actriz que su papel consiste en ser ella quien lleve los pantalones en la escena: excesivo amor a su arte, del que se arrepentirá el día en que se entere de que ese modo no está a la altura de sus hermosas faldas ("Premáticas y desahogos", Correo Literario, n ${ }^{\circ} 11,1944: 2$ ).

A arte pictórica tivo gran resonancia nas páxinas de Correo Literario, pois Seoane era un dos seus artífices e xunto a el estaban fincados en Arxentina outros artistas galegos como Daniel Castelao ou Manuel Colmeiro. Por iso, dedicáronse á pintura diversas sentenzas, algunhas concentradas en expresar a súa oposición a Diego Rivera, pintor mexicano e gran expoñente do muralismo, xa que tomara certas decisións que prexudicaban aos artistas desterrados en México ${ }^{4}$ :

Cierta pintura, mural o no mural, resulta sin proponérselo terriblemente moral: es como si al decir una frivolidad, el cielo nos arrojara al rostro un cuajarón de sangre estúpida ("Premáticas y desahogos", Correo Literario, nº 1, 1943: 2).

El gran pintor no recordaba cuando decía que la pintura se huele, que, a veces, esto es lo malo ("Premáticas y desahogos", Correo Literario, no 8, 1944: 2).

Ese tonel de pintura que es Diego Rivera... (“Premáticas y desahogos", Correo Literario, $\mathrm{n}^{\circ} 8,1944: 2$ ).

A sección tamén acolleu, en dúas ocasións, desafogos ao redor da Segunda Guerra Mundial. Nun deles mofábase dos nazis, a quen comparaba cos norteamericanos, e na outra arremetía contra os ingleses e a súa afección para afundir frotas inimigas, xa fosen as españolas no pasado ou as alemás no presente:

No es que los ingleses odien absolutamente todo lo que flota: lo hunden por mero espíritu deportivo. Y con la misma eficacia conque los alemanes odian cuanto vive sobre la tierra. Hay sin embargo una diferencia: los ingleses se quedan solos en el mar, lo cual quiere decir que triunfan, mientras los alemanes

4 Pódese consultar, entre outros, o artigo de Mauricio César Ramírez Sánchez titulado "El muralismo mexicano y los artistas del exilio español" (2010). 
se quedan solos en la tierra, lo cual quiere decir que pierden ("Premáticas y desahogos", Correo Literario, no 4, 1944: 2).

Así como los nazis son los inventores de la guerra relámpago porque carecían de recursos para hacer la gran guerra, la guerra clásica, los yanquis son los inventores de la novela relámpago, del cine relámpago y, en general de la vida relámpago ("Premáticas y desahogos", Correo Literario, nº 8, 1944: 2).

De todas as notas aparecidas, as máis acedas foron as dedicadas ao mundo literario. Eran críticas moi concretas, sen mencionar nomes, de modo que no seu momento serían entendidas polos implicados, pero, a día de hoxe, poden resultar indescifrables. Estaban dirixidas a escritores e revistas coetáneas cos que o grupo de intelectuais máis ligados a Correo Literario tiñan disputas impresas:

Ese señor cuyas obras completas son un prólogo y medio cuento, cuyas lecturas se limitan a los suplementos dominicales de la prensa en boga, cuyos títulos para justificar su existencia en este mundo son una voz hueca y una pobre cabecita llena de pedantería, anda estos días, todos los días, por esas calles de Dios, agitando su pereza en vanas conversaciones de costurerilla displicente cuyos desaires, a pesar del tonillo ofensivo, no son otra cosa que ganas de aventura. Y es que hay gentes que quieren ver mezclado su nombre, ya que no a sus obras, a sus intenciones ("Premáticas y desahogos", Correo Literario, n 2, 1943: 2).

Los escritores que hacen cierta revista de cuyo nombre no queremos olvidarnos, confiesan en un arranque de sinceridad, en un comentario de su sección editorial: "No ignoramos que la profesión de escritor obliga a cometer muchas tonterías" ("Premáticas y desahogos", Correo Literario, no 2, 1943: 2).

Qué ganas tenemos de preguntarle a ciertas personas: ¿para qué vive usted? Si no lo hacemos es porque nos tememos que nos contesten: para hallar la finalidad de la novela.

Porque el gran poeta advirtió aquella famosa muerte de perfil, el limitado lírico nos habla ahora de una muerte de sesgo, como la de los retratos de pasaporte. Las fotografías de ciertos autores revelan hasta qué punto el hombre de letras se deja arrastrar por una coquetería que no está de acuerdo con su estilo literario. Así, cuando conocemos por fotografía al autor de ese libro desesperado, nos encontramos con una cara feliz acostumbrada a nadar en pleno dulzor, casi absolutamente enmermelado.

No se comprende por qué ese poeta empleado, bien comido, bien dormido, bien leído, bien peinado, sufre de soledad agónica. Si bien parece cierto que no tan sólo de pan vive el hombre no está muy claro cómo puede escribir solo de soledad, ni existir solo de agonía pulcra y ordenada, higiénica e inteligente (Cojuelo, "Premáticas y desahogos", Correo Literario, no 7, 1944: 2). 
Aquellos que firman sus versos con el nombre y apellido de sus papás ilustres, debían ser juzgados como los que ponen al pie de un cheque la firma de un crédito ajeno. De ese modo nos evitaríamos el rubor de ver cómo ciertos nombres gloriosos van al pie de ciertos versos gloriosos también, pero, por diferentes razones ("Premáticas y desahogos", Correo Literario, no 8, 1944: 2).

De todos os desafogos escritos sobresaen especialmente aqueles que dan título á sección, as "premáticas" ou leis que ás veces podían parecer disparatadas, pero que son mostras consumadas da "arte de ingenio". Moitas destas ideas estaban centradas na cultura libresca, da que eles formaban parte e tan ben coñecían:

CONSEJO: Vete inventando tus memorias para cuando el editor lo exija.

OTRO consejo: Cuando digan malas palabras sobre tus buenas obras, eso es señal de que los tontos se sienten ofendidos ("Premáticas y desahogos", Correo Literario, $\left.\mathrm{n}^{\circ} 2,1943: 2\right)$.

Los premios literarios son siempre un pretexto para convertir en texto lo que es solo un pretexto para ganar el premio.

Los precios de los libros han subido, lo cual quiere decir que los autores ganan lo mismo y que el público paga más ("Premáticas y desahogos", Correo Literario, $\mathrm{n}^{\circ}$ 6, 1944: 2).

Tamén chama a atención a multitude de pensamentos dedicados á contorna literaria, especialmente da crítica, que utilizaba termos como "mozo" para adxectivar a quen facía xa un tempo que entrara na madurez; que non ofrecía recensións sinceras, senón textos impregnados polo "amiguismo" e o favoritismo, mentres defendían o uso da liberdade na súa escritura. Tamén arremetía contra as empresas editoriais, que non só deixaban sen cobrar aos escritores, senón que tamén trataban con desprezo aos noveis.

A biografía de Varela e o círculo de desterrados permiten saber que estas acusacións non eran presuncións, dado que moitas parecían estar baseadas nas súas experiencias. Tal sería o caso da primeira das "premáticas" que citamos a continuación, ligada a Correo Literario, onde, segundo Antonia Pérez Rodríguez (2005), Lorenzo Varela encargouse do labor publicitario, así como da revisión da distribución, mentres Cuadrado captaba máis anunciantes grazas aos seus dotes como relacións públicas:

$¿$ Se han detenido ustedes a calcular la edad de ese joven escritor, ese pintor, ese músico, a quienes la crítica rutinaria llama jóvenes? No nos referimos, natural- 
mente, a la edad física, que ya sería crueldad, sino a la de su espíritu ("Premáticas y desahogos", Correo Literario, n $2,1943: 2$ ).

El estruendoso éxito de una obra depende: un diez por ciento de la editorial, un veinte por ciento de la publicidad, un veinte por ciento de la crítica diaria de la gran prensa seria, un cinco por ciento de las revistas literarias de minoría, un treinta por ciento del distribuidor y de los libreros, un cinco por ciento de la crítica honesta. El restante diez por ciento depende, a partes iguales, del acierto del título y del valor verdadero del libro.

Hay escritores, artistas, hombres, que descansan muellemente en el blando almohadón del mimo, a los cuales les sale una literatura o una pintura gordita, palidita, azucaradita. Eso no es lo malo. Lo peor es que su alma va tomando, ante la consternación de Dios, la lisura que le queda de la lectura de las críticas amables, insípidas, que los escritores de la cofradía del mismo escriben sobre sus obras en la gran prensa y en la pequeña prensa. Y un alma lisa es un alma resbaladiza por la que pueden deslizarse igualmente la bondad inocente y la maldad premeditada. Todos los conocemos: son esos caballeretes cuya virtud superior es la de no hacer nada que previamente no haya sido aceptado como moneda de curso legal. Esta es la razón por la cual sus obras tienen siempre esa corrección, ese atuendo algodonado, esa puntualidad despiadada. Y sobre todo, a eso se debe que de puro oficiales, y sólidas, parezcan como avaladas por una gran organización bancaria, por la gran gerencia, calva, eficiente, imponente, de las letras y las artes. Y en los mofletes de la cara parecen llevar un sello pomposo que dice: Rostro de curso legal.

Tres, cuatro, cinco, seis $-\mathrm{x}$ editoriales- se apresuran a editar un mismo libro, consagrado, venerable, por cuyas páginas corre el prestigio con cierta luz de gloria imperecedera. El autor ha muerto hace cien, doscientos, quinientos años. Los siglos dan al título un marchamo feliz, una autoridad segura, incontrovertible y hasta atemorizada porque viene del tiempo y porque dende el Olimpo tenemos la sensación de que alguien espía nuestras cavilaciones, vigila nuestra loca pero posible disconformidad. A la vista de esas casi siempre apresuradas ediciones nos preguntamos, nos hacemos a nosotros mismos la pregunta eterna: ¿Qué pasaría si el gran autor clásico resucitase y llevase a las editoriales una obra actual, desconocida, rara, y hasta opuesta a la que entonces escribió, sin la experiencia de tanto tiempo de muerte, de Olimpo, de calma trasmundana? ¿Habría alguna editorial en este mundo, alguna gran editorial, alguna poderosa editorial, que le editara el libro? El bohemio que está junto a nosotros se permite decir que eso es posible, que lo que no sería posible dende luego es que le editaran el mismo libro sobre el que ahora marchan tantos batallones de editores, si de repente se viera en la necesidad de ofrecerlo como un original, como una novedad.

En este mundo solo hay libertad tolerada a medias: la libertad de elogiar. Se habla mucho de la necesidad de una crítica literaria libre: cuando se ejerce alguien se encarga siempre de formar tribunal y entablar proceso contra el crítico. Y 
siempre actúa de fiscal un amigo de hacer favores y pasar la cuenta. El papel del juez le queda reservado al autor que el crítico comenta. Unos cuantos agentes de publicidad y algunos industrializadores de la cultura, tratan de poner orden en la sala y de amordazar al ingenuo comentarista. En un rincón, cubiertos de sobrecubiertas y de prólogos, y de pruebas de imprenta y de menús de banquetes homenajeantes, yacen siete cadáveres, los cadáveres de las siete musas. Un personaje siniestro trata de llegar desesperadamente pronto, para que nadie lo note, al rincón terrible: es el enterrador, el gran amigote de las causas ganadas ("Premáticas y desahogos", Correo Literario, n 3, 1943: 2).

Outros escritos ían dirixidos simplemente aos escritores, a aqueles que non tiñan futuro pola súa falta de dotes literarios, a quen parecía non importarlles nada polo seu gran sentido do humor, aos que se escondían baixo a autoría anónima etc.

Las aves negras de la literatura, que son hombres de pluma en puño que obtienen publicidad para sus publicaciones, pueden aspirar a que les acepten un guión cinematográfico. Pero no tienen el derecho ni el deber de anhelar locamente el título de Académicos de la Lengua, a no ser por aquella función que puede realizar esta de pegar sellos en un escritorio poco moderno ("Premáticas y desahogos", Correo Literario, no 10, 1944: 2).

Deseemos a todos nuestros enemigos un destino de traductores, que es lo peor que les podemos desear. Exprimidos por los editores, odiados por los lectores, denunciados por los críticos, y siempre sobre el fantasma de la página del crimen, la palabra violada, el verso convertido en conserva editada ("Premáticas y desahogos", Correo Literario, nº 11, 1944: 2).

Como no caso das seccións "Nuevas" e "Rehilete en el viento", non faltaron sátiras e comentarios humorísticos contra a cultura española do Réxime e os intelectuais españois ligados a ela. Entre os nomes sobresaíron figuras afíns ou aceptadas polo Réxime Franquista como Manuel Machado, José María Pemán, Jardiel Poncela, Gerardo Diego ou Ramón Pérez de Ayala.

Sobre España resaltaban xocosas notas como a seguinte, que facía referencia aos múltiples nomeamentos que se sucederon nas diferentes reais academias españolas (historia, arte, lingua, etc.) tras a ausencia dos seus membros desterrados:

Estaba tan oscuro que no se veía un académico a dos pasos (Cojuelo, "Premáticas y desahogos", Correo Literario, n 5 , 1944: 2). 
Estoutra apostilaba os criterios de selección de libros da España oficial onde se desdeñaban obras de Unamuno, mentres o seu recoñecemento crecía máis aló das fronteiras:

Los libros de Unamuno carecen de importancia filosófica. Esto dicen en España los que carecen ya de importancia existencial ("Premáticas y desahogos", Correo Literario, $\mathrm{n}^{\circ}$ 10, 1944: 2).

E a seguinte volvía acordarse de Gerardo Diego:

Si hay algo que se parezca a una calamidad, espiritualmente hablando, ello es la última producción de Gerardo Diego, metido de pronto a enterrador de banderilleros, sin que le sirvan las alas que en vano intenta robarle a Alberti, ni el cinismo manolo del Machado menor ("Premáticas y desahogos", Correo Literario, $\left.\mathrm{n}^{\circ} 1,1943: 2\right)$.

Tamén atopamos máis referencias ao gaditano José María Pemán, unha das figuras máis atacadas por Varela dende a distancia. Nesta ocasión lembrou un poema do gaditano, concretamente de Barrio de Santa Cruz (1931), ao que engadiu un final hilarante ("Premáticas y desahogos", Correo Literario, $\left.54 \mathrm{n}^{\mathrm{o}} 2,1943: 2\right)$ :

El amigo discreto nos comunicó que le faltaba un verso a esta tirada de ellos que pertenece a José María Pemán:

VOLVERÁ, sí, la guitarra, -esa que rompe y desgarra con ayes el corazón; volverá a hablar de pasión, de un flamenco entre los brazos, cuando le quitan los lazos que ahora lleva de crespón, y volverán a sonar juntos guitarra y cantar, con sus gritos de pasión y sus notas de ilusión y sus ternuras risueñas... Pero ¡aquellas malagueñas de don Antonio Chacón! $\mathrm{Y}$ el amigo discreto agrega: Esas no VOLVERÓN. 
Xunto a Pemán compareceu o escritor e diplomático Ernesto Giménez Caballero, coñecido fascista, a través de dúas "premáticas". A primeira era unha proposta de epitafio, dous cuartetos que evocaban un coñecido poema de Quevedo, para mostrar os ideais e intereses que movían a Giménez; e a segunda delas recuperaba o experimento literario surrealista de Giménez Caballero, titulado $Y_{0}$, inspector de alcantarillas, onde se expresaban as calidades principais que o autor da sátira vía nel (Cojuelo, "Premáticas y desahogos", Correo Literario, $\mathrm{n}^{\circ}$ 5, 1944: 2):

\section{Epitafio}

Aquí yace Giménez Caballero.

Poderoso es Don Dinero.

Pero la muerte no mató al banquero:

Le mojó la pluma, le llenó el tintero.

Otro al mismo:

En esta alcantarilla, caminante, reposa el literato y el tendero: dos muertos en un cuerpo degradante en un solo cadáver verdadero.

Na seguinte mención comentáronse os problemas que a obra mestra de Miguel de Cervantes experimentaba na España do Réxime. Á mantenta desta expoñíase unha pregunta retórica que apelaba ao lector e, especialmente, a Giménez, co obxectivo de saber se había relación algunha entre o tolo e idealista Don Quixote e o simple e parvo Cacaseno de Historia de la vida, hechos y argucias de Bertoldo, la de su bijo Bertoldino y la de su nieto Cacaseno de Juan Xusto Uguet, tamén vítima da persecución e o esquecemento:

Bien sabe Giménez Caballero que hay que amar al prójimo como a ti mismo. Pero el Quijote, ¿es prójimo de Cacaseno? (Cojuelo, "Premáticas y desahogos", Correo Literario, $\mathrm{n}^{\circ}$ 5, 1944: 2).

Como vimos en "Carta abierta", o Quijote quíxose censurar en España e isto deu lugar a que se producisen anécdotas similares (Cojuelo, "Premáticas y desahogos", Correo Literario, no $5,1944:$ 2):

En Madrid andan dando las vueltas para suprimir el Quijote. Ahora sí que va a ser muy oído en labios de los maestros aquella célebre respuesta de uno de ellos al ministro de Instrucción Pública, cuando este, hombre serio habitualmente, preguntó con aire grave a la clase: 


\section{— ¿Quién hizo el Quijote?}

Un alumno, el que se sentía aludido por el ministro, se echó a llorar. Como este buscase otro al que hacerle la pregunta, toda la clase puso cara de congoja, y, finalmente, el pobre maestro, atribulado ante la mirada interrogante del ministro, se apresuró a decir:

- Yo no fui, señor; se lo juro.

Ademais, contara con pouca fortuna á hora de proxectarse noutras linguas, como apuntaron nesta enxeñosa sentenza:

La lectura de ciertos ensayos sobre Cervantes, hace pensar si la sombra de Avellaneda no estaría actuando en el momento en que se hacían ciertas traducciones del Quijote a idiomas como, por ejemplo, el alemán ("Premáticas y desahogos", Correo Literario, nº 6, 1944: 2).

As figuras españolas que eran obxecto de burla ás veces eran desterradas, como o poeta Juan José Domenchina, ligado á Xeración do 27, que no seu desterro mexicano tivo diversos problemas, non só con Varela, senón tamén de inspiración e co alcol.

Detrás de esta palabra: Domenchina, es fácil comprender que no hay más que un hígado maltratado por las musas vengadoras ("Premáticas y desahogos", Correo Literario, $\mathrm{n}^{\circ}$ 4, 1944: 2).

Ou como o afamado pintor malagueño Pablo Picasso:

Dende su cima variable, Pablo Picasso echa una mancha protectora, al limpiar sus pinceles, sobre la obra de los pulgarcitos que se apretujan a sus pies tratando de comerle las raíces más débiles (Cojuelo, "Premáticas y desahogos", Correo Literario, $\mathrm{n}^{\circ}$ 7, 1944: 2).

Noutras ocasións tratábase de personalidades españolas que abandonaron o país tras a guerra, con ou sen vinculación política, pero sinalados polos seus actos. Tal foi o caso de Salvador Dalí e a súa controvertida actitude de vida, que o levou a mergullarse en posicións políticas opostas:

Se parecían tanto aquellas mellizas, que decían de ellas: la una es la vida secreta de Salvador Dalí, la otra la vida pública ("Premáticas y desahogos", Correo Literario, $\left.{ }^{\circ} 1,1943: 2\right)$.

Tamén se fai referencia a Ramón Pérez de Ayala, activista republicano coñecido por unhas controvertidas opinións respecto a Azaña e a Segunda 
República e que regresou a España tras a guerra. Cuestións políticas aparte, tamén era lembrado polos seus copiosos e arrevesados textos:

Nadie le niega a Ramón Pérez su copiosa erudición de enciclopedia británica, ni sus dos novelas de buenos tiempos, ni su atuendo correcto y su lenguaje bien educado, ora en sazón bien lograda, ora en agriverde desliz, o bien con melifluas ínfulas, y así mismo ensamblado con aliteraciones de pecata minuta. Pero, aparte de su desdén político, lo que no entenderemos nunca, salvo que los años nos vuelvan así, es cómo soporta sus propios soponcios, cómo no se aburre nunca de su letrería, cómo tiene tanta impiedad para sus lectores, cómo no se cansa de prometer el tema que siempre se olvida de desarrollar.

¿Tendremos que llegar a la conclusión de que Ramón Pérez no se lee a sí mismo sus artículos? ¿Nos veremos obligados a creer que no los escribe sino que los embute y los recorcha para que floten mientras la musa de los cargosos los ampare? ¿Cómo se puede escribir así, con las manos llenas de masa, los ojos latinajeados, pariendo palabras hipopotámicas con gesto de salmista desertor? ¡Pobre, desdichado, repetido Ramón Pérez de Ayala! (Cojuelo, "Premáticas y desahogos", Correo Literario, no 5, 1944: 2).

"A propósito de Dickens", don Ramón Pérez de Ayala diserta en un enjundioso artículo -fruto de su renovada lectura de los inmortales "Pickwick Papers"-, en el que demuestra al lector que "la novela es un arte de hombres maduros", cuando no algo más.

"A propósito de Dickens", el "Inimitable Boz", escribió el Pickwick a los 24 años (?) ("Premáticas y desahogos", Correo Literario, n 11, 1944: 2).

O mesmo lle ocorreu a Orson Welles quen, a pesar de apoiar á República durante a guerra, tamén deu pé ao humor nesta sección:

Si de nosotros dependiera, Orson Welles no se casaría con Rita Hayworth, sino con cualquiera de esas tremebundas ensayistas que tienen la belleza de la arquitectura de Gaudí y la gracia literaria de André Bretón ("Premáticas y desahogos", Correo Literario, nº 1, 1943: 2).

"Premáticas y desahogos" tamén se fixo eco da acollida de Correo Literario e das polémicas que mantivo cos seus lectores, con outras publicacións e en actos relacionados con ela. Así se mostraba na seguinte nota, onde se lembraba a acusación dalgúns lectores de falta de agresividade nas notas de "Libros y Autores", feito que se xustificaba do seguinte modo:

Si nos gustara el escándalo podríamos hacer en CORREO LITERARIO una sección de verdadero éxito, publicando con pelos y señales las quejas que verbalmente llegan por nuestra "falta de agresividad" en los comentarios de libros. 
Pero ni nos atrae el escándalo por sí mismo ni queremos aprovecharnos de un instante de sinceridad de las gentes ("Premáticas y desahogos", Correo Literario, $\mathrm{n}^{\circ}$ 9, 1944: 2).

Ou naquela que poñía de relevo a repercusión que tivera o banquete en honra a Seoane organizado por Freitas, do que se fixeron eco tamén "Columna en Portugués" e "Carta Abierta":

Recomendamos a Newton Freitas que no lleve a cabo el banquete de cargosos que se propone realizar, y en el que ha puesto hasta ahora tanta diligencia y tan difícil tacto para no olvidar ninguno, para que nadie se pueda sentir resentido por no haber contado, dende el primer momento, con su pesada persona. No es que los cargosos no se merezcan ese homenaje al secante. Es que después del banquete subirían de paso hasta tal punto, que sería forzoso no soportarlos un solo instante. Lo que se les debe dar a los cargosos no es un banquete, sino un régimen dietético que nos atormenta. $\mathrm{Y}$ aun esto habría que pensarlo, pues correríamos el riesgo, al extraerles la cargosidad, de dejarles sin finalidad en esta vida. Y no suponemos tanta crueldad en Newton Freitas, precisamente porque no es un cargoso ("Premáticas y desahogos", Correo Literario, n ${ }^{\circ} 11$, 1944: 2).

Hemos de decir en homenaje a la verdad, que el homenaje a los cargosos, ha ya ganado la voluntad de los organizadores más discretos, que, por serio, se apresuran a figurar entre los homenajeados, librándose así del sinsabor de verse incluidos sin ser consultados. Tenemos entendido que en el banquete a estos, entre los que nos incluimos por las razones ya apuntadas, comeráse a un solo carrillo, reservando el otro para mascullar palabras que han de llegar sin duda hasta los oídos de los ausentes, de los que se empeñan por inconcebible modestia en no tomar parte de los detalles preparativos de la comilona. En algunos casos, nos referimos a esos desertores, esta modestia no ha de ser perdonada. Prometemos publicar el nombre de los que deserten, para que la justicia celeste tome en cuenta su error y les recuerde que su primer deber es conocerse a sí mismos ("Premáticas y desahogos", Correo Literario, n 12, 1944: 2).

\section{"Rehilete en el viento"}

Esta sección ten, como "Premáticas y desahogos", un carácter propio e único sen precedentes nin consecuentes en publicacións posteriores alleas a este grupo de intelectuais. Só na revista que fundaron tras o cesamento desta, Cabalgata (1946-1948), atopamos unha pequena sección moi próxima, mesmo con historietas repetidas. 
"Rehilete en el viento" foi asinada en diversas ocasións baixo o pseudónimo Niporesas, que podería corresponder a Luis Seoane e, especialmente, a Lorenzo Varela, dado que este último era o artífice da outra sección de tinguiduras burlescas da revista. O pintor non confesou nada respecto a isto, quizais porque a súa pluma ou os seus recordos tamén estiveran presentes.

O pseudónimo era unha homenaxe a Mariano José de Larra e o seu Andrés Niporesas. A admiración polo costumismo español máis agudo e incisivo emparenta este pseudónimo co de Cojuelo, o que reforza a nosa sospeita de que tras ambos debeu moverse a mesma pluma: a de Lorenzo Varela.

Estaba composta por varias anécdotas xocosas de personaxes designados con iniciais moi evidentes por tratarse de figuras de relevancia internacional ou por ser afíns ao círculo dos exiliados. Os seus protagonistas, de distintas nacionalidades, mesturábanse para configurar un gran fresco de risibles historias atribuídas, onde sobresaíron as iniciais de españois como R. del Valle Inclán ou M. de Unamuno.

A partir do cuarto número, os personaxes recuperaron os seus nomes completos á fronte destes recordos, comentarios ou quizais invencións.

Co paso do tempo, a cantidade de historietas reduciuse aos poucos. Deste xeito, só aparecían un par de anécdotas cun desenvolvemento maior e, a partir do número vinte e cinco, unha soa. "Rehilete en el viento" apareceu practicamente en todos os números, pois só faltou no catorce, vinte e sete, vinte e nove, trinta e catro-trinta e cinco e trinta e nove.

Pola súa abundancia, por tratarse probablemente de historias verídicas e pola relación que houbo entre os exiliados redactores da revista e os protagonistas, os españois son o centro do noso interese. Tratábase de personaxes de distintos ámbitos e épocas. Tal foi o caso de Emilio Castelar e Emilia Pardo Bazán, representados nunha curiosa anécdota cuxa veracidade descoñecemos ("Rehilete en el viento", Correo Literario, no 7, 1944: 4):

Durante largos años fue la trastienda de la famosa librería de Fernando Fe, sita en una de las entradas de la madrileñísima Puerta del Sol, centro de reunión de políticos y literatos. Allí se encontraba, departían, informábanse de las últimas novedades editoriales y alguna que otra vez -muy pocas, es cierto-, compraban algún libro. Un atardecer en que ya cercana la hora de cerrar, se encontraron 
Don Emilio Castelar, académico, y Doña Emilio Pardo Bazán, que nunca lo fue a causa del veto que a su sexo se imponía el reglamento de la "docta casa", el tribuno le leyó a la autora de "Los Pazos de Ulloa", la ficha que allí mismo y a vuela pluma había redactado para el Diccionario.

—Escúcheme, Doña Emilia. - "Liga". "Trozo de cinta o goma elástica que las mujeres se ponen debajo de la rodilla para sujetarse las medias".

— ¡Por Dios, Don Emilio!... ¡Cómo se conoce que usted no le ha visto las piernas más que a su cocinera!...

Entre os personaxes históricos destacaron outros como o monarca español Alfonso XII e a súa segunda esposa, Dona Cristina:

Don Alfonso “equis dos palitos”, era un rey chungón y dicharachero, amigo de la juerga y de las buenas mozas. Casóse en segundas nupcias, y por razón de Estado, con una princesa que iba para monja, y que más valía que lo hubiera sido. Esta, austriaca del Sacro Romano Imperio -“¿qué se hizo el rey Don Juan?”...aprendía el castellano de labios de su real consorte, quien al enseñarle la lengua de Cervantes, lo hacía conforme a la jerga de los devotos de Monipodio.

Un día que la austera dama hubo de felicitar a Don Antonio Cánovas del Castillo, a la sazón presidente del Consejo de Ministros, lo hizo en los siguientes y poco protocolares términos:

60 -Hola, Canovitas, mi enhorabuena. Me han dicho que ayer en las Cortes, estuviste hecho un barbián.

—Vuestra benevolencia me abruma -repuso "Canovitas", inclinándose profundamente-, y el "barbián" es con toda seguridad, el que ha informado a Vuestra Majestad (Niporesas, "Rehilete en el viento", Correo Literario, no 8, 1944: 4).

Como podía esperarse, Isabel II tamén foi protagonista dunha das historietas, onde se reflectía a imaxe que tiña o pobo da súa monarca ("Rehilete en el viento", Correo Literario, no 21, 1944: 2):

Doña Isabel II, reina castiza y generosa de sí y de su corazón, gustaba también de reunir en alguno de los menos fríos salones del inmenso palacio de la plaza de Oriente, su tertulia de escritores, políticos y cortesanos -intelectuales que diríamos ahora-, donde se comentaba toda la actualidad tanto política como literaria. Acababa de subir, merced a un "pronunciamiento", un famoso espadón al poder. Nadie comentaba la actualidad, pero La Señora, viendo retozar una chispa de malicia en los miopes ojos del cantor de "Los Amantes de Teruel", don Juan Eugenio Hartzenbusch, le amenazó con el abanico, diciéndole:

-Miren a aquel tan pequeñín y tan malo... ¡Qué no habrá pensado!... ¿Es de política?... Pues no lo digas... O dilo de una vez, que a mí también me gustan los chismes. 
- Señora, es solo una cuarteta... Un comentario a la alegría popular que ha recibido al nuevo gobierno... Dice así:

Cuando comenzó el diluvio

Todos estaban alegres,

Y decían muy contentos:

¡Qué buen año va a ser este!...

Tamén apareceron personaxes do mundo da arte como Francisco de Goya, lembrado a través dunha historia oída ao seu porteiro. Grazas a ela coñecemos como supostamente conseguiu recrear a escena dun dos seus cadros máis afamados ("Rehilete en el viento", Correo Literario, n 11, 1944: 4):

Esto lo contó el portero de la "Quinta del Sordo".

"El Sordo", era Don Francisco de Goya y Lucientes, baturro por su carne, español por su alma y universal por su pintura. La "Quinta", es la que por muchos años habitó cerca de la ribera del Manzanares, entre La Casa de Campo, el Pardo y la Moncloa, en las afueras del Madrid de su gloria.

Una noche, "lóbrega noche, eterno asilo del caminante que esquivando el sueño, en su silencio pavoroso gime"... La noche del 3 de mayo de 1808, salió el pintor, armado de cartón y pinceles, a tomar apuntes de los mártires fusilados en la montaña del Príncipe Pío. El portero le acompañaba temeroso del ambiente, pero más temeroso de su amo, que le obligaba a llevar una gran linterna con que iluminar aquellos "desastres de la guerra"... El pintor dibujaba - ¡muertos! ¡muertos por todas partes!- rápida y sintéticamente. Allí estaban "los fusilamientos" y todo lo demás... Las horas pasaban y con el aumento de las sombras aumentaba el terror del asustado lacayo, que finalmente, haciendo de tripas corazón, gritó al oído del "sordo" pero no "ciego".

-Pero, Don Francisco... ¿Para qué hace usted esto?

_ ¡Para que vean los hombres lo brutos que son! ¡Para que vean!

Entre os escritos atopamos esta divertida anécdota de Lope de Vega ("Rehilete en el viento", Correo Literario, nº 23, 1944: 2):

Cuéntase -y el que lo cuenta es Lope de Vega-, que de valor y temor ahora que estamos en guerra, más vale no presumir que no te salga la criada respondona. Cuéntase, que luego contaré yo otra no de tanta alcurnia, que un día en la tienda del Gran Duque de Alba alguien le leyó el siguiente epitafio: "Aquí yace Velasco Fernández, que nunca tuvo miedo". A lo que respondió el duque primero y único de su estirpe, a quien se lo contaban: "Ese hombre nunca llegó a despabilar una vela con las manos".

O cinema tamén orixinou diversas historietas, como a protagonizada pola actriz bonaerense Lola Membrives, de pais emigrantes españois, que desen- 
volveu a súa carreira entre España e Arxentina. Relacionouse cos grandes do teatro da época, tales como os Irmáns Machado e Benavente, quen mesmo escribiron papeis para ela.

Lola Membrives, alta figura del teatro de habla hispana, ensayaba en el escenario de Teatro Goya de Barcelona, la próxima representación de uno de sus grandes éxitos: "Pepa Doncel”, de don Jacinto Benavente.

Tenía como compañero en la escena culminante de la obra a aquel grande e inolvidable actor que fue don Francisco Morano. Actriz y actor ponían a prueba sus opuestos temperamentos, en un torneo que era una magnífica lección del arte de representar.

De pronto, doña Lola interrumpió su escena y dirigiéndose a Morano, le dijo: -Perdone usted, don Paco, pero yo tengo costumbre de quedarme aquí delante durante esta escena... Usted pasa aquí atrás y...

— ¡Claro! -exclamó "Don Pedro”-. ¡Pero eso era antes, señora! Cuando esta obra era "Pepa Doncel” y no ahora que es: ¡"Pepe Doncel”!... ("Rehilete en el viento", Correo Literario, n 33, 1945: 2).

Varios personaxes resgardados baixo o Franquismo foron diana das súas críticas, especialmente do mundo cultural, ao que os compoñentes desta revista sempre estiveron ligados. Entre eles sobresaían figuras como Gerardo Diego, que xa foi branco de burlas noutra sección, co que colaboradores e compoñentes da revista participaron en diversos proxectos antes da Guerra Civil Española:

Gerardo Diego Cendoya, catedrático de preceptiva, retórico del ultraísmo y clásico de la Falange, todo en una pieza, andaba -hace de esto algunos años-, cabizbajo y tristón por las terrazas de los cafés madrileños. Pianista entre poetas y poeta entre pianistas, el pasadero sueldo de su cátedra amén de los gajes de la misma, no hacía suponer en él apuros económicos de ninguna índole. Interrogado por algún amigo, deseoso de informarse del motivo lírico de su desasosiego, el cerebral cantor de $\mathrm{X}$ y $\mathrm{Z}$ le contestó con atribulado semblante: -No sé qué hacer... Ese Altolaguirre... Le di doscientas pesetas para que me imprimiera un libro de poesías en su imprenta... "La Verónica"... ¡De esto hace ya seis meses y ni palabra!... Y ahora me entero de que anda por ahí haciendo viajes, comprándose joyas, manteniendo queridas, amueblando pisos, regalando pieles... No quiero pensar mal, pero mis doscientas pesetas... (Al cambio ochenta pesos) ("Rehilete en el viento", Correo Literario, n 36, 1945: 2).

$\mathrm{Na}$ mesma liña, outro branco habitual das burlas era o escritor novecentista Eugenio D’Ors, que protagonizou diversas anécdotas en Correo Literario e na súa sucesora, Cabalgata: 
Él, el Maestro del Molino de Viento, el Profeta del Valle de Josafat, el Hombre de la bien plantada, tres Xenius y un solo D'Ors verdadero, interrogaba con su voz grave a una muchachita que pretendía entrar de secretaria a sus costas. Una vez aceptado lo magro de estas últimas, admirado de los conocimientos -mecanografía, taquigrafía, francés- que adornaban a aquel portento de saldo, el Goethe de la Barceloneta hizo una última pregunta:

- ¿Conque sabe usted francés señorita?

-Yes, mister D'Ors...

— ¡Eso no es francés, es inglés!

— ¡Huy!... ¡También sé inglés! -exclamó maravillada la secretaria... ("Rehilete en el viento", Correo Literario, n 6, 1944: 4).

Dado que Correo Literario se editaba na Arxentina, onde tiña o maior número de lectores, subscritores e colaboradores, non faltaron as intrigas relacionadas con este país. Por esta razón, atopamos a seguinte historia dedicada ao político, xornalista e escritor arxentino Belisario Roldán, de ideas socialistas, que participou en varias ocasións nos asuntos de España e faleceu case un par de décadas antes da chegada dos desterrados á súa patria:

Belisario Roldán, poeta y escritor de fácil palabra y galana pluma, era un devoto ferviente del culto del veleidoso dios Azar, quien quizás por aquello de "afortunado en amores...", no se le mostraba propicio reduciendo a la nada el monto de sus ofrendas, lo que le tenía siempre a la cuarta pregunta. Uno de sus muchos días en que se encontraba en la dicha "cuarta" y no tenía medio de remediarse ya que el general Mitre había ordenado que no se le facilitara dinero sin su refrendo personal, el poeta y orador decidió ver al águila en su nido, y ni corto ni perezoso llegóse al domicilio del director-propietario de su diario y sin hacer caso del negro que le impedía el acceso, entró hasta el despacho de Don Bartolo.

El general, que se encontraba atareadísimo ante una enorme mesa agobiada de papeles y librotes, alzó la vista y le interrogó con la mirada. Roldán, por decir algo, preguntó:

—¿Qué, mi general, trabajando?...

—Sí, mi hijo, no se lo digas a nadie, pero... jestoy traduciendo la "Divina Comedia"!

- ¡Duro, general! -le animó el poeta-, hay que jorobar a estos gringos (Niporesas, "Rehilete en el viento", Correo Literario, no 8, 1944: 4).

Entre os españois que protagonizaron estes relatos non faltaron figuras pertencentes ao exilio español, o que nos fai valorar dun modo máis positivo a revista e a sección, xa que non só se ría de adversarios ideolóxicos, senón tamén dos seus modelos e compañeiros de desterro. Deste xeito atopa- 
mos a un dos grandes mestres do exilio, de quen reproduciu unhas graciosas anécdotas:

M... de U..., vasco universal, castellano de vocación, paradoja viva de España, fue interrogado en París por una dama, muy versada en última moda cultural.

—Dígame, Don Miguel; en España, ¿qué piensan las mujeres de Freud?... Don Miguel, sin sacar del pecho su barbita de pájaro despiertísimo, contestó de manera rotunda:

- ¡Señora, en España, las mujeres son decentes! ("Rehilete en el viento", Correo Literario, $\mathrm{n}^{\circ}$ 3, 1943: 4).

En la Imprenta de la Revista de Bibliotecas, Archivos y Museos, de Madrid, había una dotación de correctores, al lado de los cuales toda la sabiduría de los Nebrija, Valdés, Pérez de Oliva, Luzán, Hermosilla, Bello, Cuervo, etc., etc., quedaba tamañita. Gramáticos ortodoxos, su juicio era, y no sé si seguirá siendo, inapelable, para los desgraciados cuanto cultos colaboradores de aquella tan ilustre como poco leída publicación. Un día, don Miguel de Unamuno, que en "su" gloria esté, al recibir unas páginas de segunda prueba, vio subrayada con lápiz rojo la palabra "oscuro", y que al margen el corrector había puesto con grandes caracteres: " $\mathrm{O} \mathrm{Ojo}$ ! Obscuro".

Cuando el corrector recibió las pruebas de vuelta, encontróse con su advertencia "resubrayada" por don Miguel, que le apostrofaba: “¡Oreja! Oscuro” ("Rehilete en el viento", Correo Literario, no 10, 1944: 4).

Hace ya mucho tiempo, en la época en que Miguel de Unamuno era consejero de la Instrucción Pública, al ir a tomar asiento en el Consejo, vio una cara desconocida, lo que le hizo preguntar a su vecino de mesa el nombre de aquel señor. Casi todos los consejeros ignoraban la identidad del ilustre desconocido, del que al fin solo se supo que era un don Fulano, de reciente designación, doctor en Derecho, Medicina, Farmacia, Filosofía, Letras, Historias, Sociología, Química, Física, Ciencias Naturales, Ciencias Exactas y todo lo habido y por haber...

- Muy bien -dijo don Miguel, tras de observar por un momento el "lomo" de aquel Espasa humano-, esto me recuerda un viejo cuento de Mark Twain. Cuenta este, que un día, al dar su acostumbrado paseo por los alrededores de su pueblo, vio a un hombre derecho y muy tieso al pie de un árbol: los zapatos no le llegaban al suelo; la lengua le salía como medio palmo de la boca; del cuello le subía una cuerda tirante que se unía a una de las ramas del árbol; tenía los ojos saltones, no respiraba; estaba frío; muerto: se había suicidado y... además, era un imbécil... ("Rehilete en el viento", Correo Literario, n 15, 1944: 4).

Como bos galegos non excluíron das súas páxinas ao máis ilustre dos seus compatriotas durante o primeiro terzo do século XX: Ramón del Valle-In- 
clán. Lembróuselle nunha xocosa historieta que implicaba a Eduardo Marquina, dramaturgo que brillou na España franquista e diana de "Premáticas y desahogos":

Alrededor de los años 1924-25, D. R... del V... I... vivía en Puebla del Caramiñal, sobre la ría de Arosa, provincia de la Coruña, a donde solían ir a visitarle muchos jóvenes artistas que vivían cerca o se hallaban de paso por las cercanías. En cierta ocasión en que V... I... acababa de regresar de Madrid, a donde había ido por asuntos relacionados con la reimpresión de sus obras, uno de los visitantes le preguntó:

-D. R... ¿qué tal es la obra teatral de E. Marquina y Catá, de la que tantos elogios hace la prensa?

-Pues peor todavía -contestó D. R... del V... I... con su voz ceceante que zi la hubiera escrito cualquiera de los doz por separado ("Rehilete en el viento", Correo Literario, $\mathrm{n}^{\circ}$ 1, 1943: 4).

Xunto a el estaba o mestre por excelencia de moitos desterrados, Francisco Giner de los Ríos, creador da Institución Libre de Ensino e do modelo educativo que trasladaron os exiliados ás súas entidades docentes:

Don Francisco Giner de los Ríos, maestro de toda una España renacida, gustaba de pasear por la Sierra de Guadarrama, en la que saturada el alma de la belleza de los pinares de Balsain y el Paular, así como el pulmón de los gratos olores de mejoranas y resinas, gustaba el Maestro de departir, aprendiendo más que enseñando, con algún humilde pastor o cabrero de aquellos que aguardan en su habla y en su corazón la palabra y la frescura del decir del bueno y regocijado Juan Ruiz, Arcipreste de Hita.

Allí, al reparo de unos pinos, hablábale don Francisco al cabrero que le escuchaba atentamente:

-Los ingenieros construyen los puentes y los arquitectos las casas; los médicos curan y los geólogos descubren las riquezas ocultas; los filósofos buscan la verdad absoluta y los poetas hacen absoluta la belleza; los militares defienden la paz; los trabajadores crean; los maestros enseñan...

-Así, don Francisco -repuso el cabrero tras de un silencio-, que entre todos lo sabemos todo... ("Rehilete en el viento", Correo Literario, no 6, 1944: 4).

Tamén se lembrou ao gran poeta Juan Ramón Jiménez cunha anécdota relativa ao mundo da impresión de libros:

Todos ustedes recordarán seguramente los caracteres tipográficos con que se imprimía la doctísima Revista de Occidente. Pertenecían estos a una familia de la casa francesa Cochin, cuyos tipos fueron diseñados para llenar mucho espacio 
sin perder el aspecto de densidad en la composición. Tipo de letra acorde con el íntimo espíritu de la Revisa cuyas altas eles y efes producen a poco que se lea una especie de embotellamiento mental, que algunos pueden creer que sea producto de la excesiva ciencia ingerida y que no es otra cosa que desazón óptica de facilísimo diagnóstico.

J. R. J., el altísimo poeta gaditano [sic], lírico jinete del anjélico Platero, rompió con el "cerebro" de la publicación a pocos meses de aparecer aquella. La causa fue una jota o coma de más o menos, sacrilejio que el poeta no podía perdonar, y del cual se vengó diciendo a todas sus amistades: "Ustedes comprenderán. ¡Qué se va a hacer con una Revista que en cuanto ha leído uno dos o tres minutos tiene que empezar a sacarse de los ojos eles y efes que se le han metido dentro!" ("Rehilete en el viento", Correo Literario, n 6, 1944: 4).

\section{Pablo Picasso, mencionado en "Premáticas y desahogos", reapareceu nes-} ta sección cunha inofensiva anécdota, precedida por unha zumarenta concreción contextual:

Pablo Picasso, el genial malagueño, que regaló a París todas las sales espirituales de su Mediterráneo universal, es uno de los hombres que más ataques y alabanzas injustificadas haya recibido en vida. Su ingenio, unido al jamás desmentido fervor por un arte del que él es el más grande renovador que hayan conocido los siglos, le ha hecho contestar frases que, reunidas, formarían un voluminoso infolio. Dende la histérica nueva rica, partidaria de los "ismos", al estúpido fracasado que busca refugiarse en aquello que él cree fuera de toda disciplina y control, toda la fauna cosmopolito-freudiana del París que fue, ha desfilado por el estudio del rechoncho maestro de unos pocos, que todavía no han llegado a contarse entre los algo.

Cierto día, uno de estos últimos, admirador empalagoso, de los que en todo ven algo genial, no sabiendo cómo demostrar su devoción al "maestro", le preguntó con palabras que él creía eran un homenaje:

- ¡Pero, maestro! ¿Qué es lo que usted busca?

— ¡Yo no busco! -le gritó el "maestro”-: ¡Encuentro!! ("Rehilete en el viento”, Correo Literario, $\mathrm{n}^{\circ}$ 25, 1944: 7).

E, xunto a mestres e amigos españois, atopamos unha anécdota da Guerra Civil Española:

Y esta, que no tiene tan ilustres progenitor y protagonista, sucedió en Madrid, allá por el año 1937. Dos modistas, jóvenes, bastante delgadas pero animosas y decidoras, bajaban por la Gran Vía, vulgo “Avenida del Quince y medio", en horas de una tarde a justificar el trágico apodo. Caían los cañonazos, a voleo y sin objeto ninguno, y una de las muchachas echó a correr atemorizada, al 
paso que la otra, sin cambiar un punto su paso presumido, le gritó con estoico desgarro:

- ¡No corras, chica!... ¡No corras, que a lo mejor te la encuentras!... ("Rehilete en el viento", Correo Literario, no 23, 1944: 2).

Entre os lembrados nestas historietas sobresaía un importante grupo de intelectuais esquecidos con quen compartiron a súa mocidade os compoñentes de Correo Literario no Madrid dos anos trinta. Traían á memoria estas figuras pensando, especialmente, nos lectores desterrados, quen entenderían con maior precisión a fondura destas anécdotas. Entre eles atopamos a Pedro Luís de Gálvez, poeta malagueño de controvertida biografía e carácter ácrata que, durante a guerra, axudou a personalidades de ideoloxías dispares e foi condenado a morrer tras o fin do conflito, a pesar de non implicarse nel de forma activa:

¡Oh, la bohemia! En el Café del Prado, en Madrid, de tan ilustre tradición picaresco-lieraria, una “desapacible noche de Invierno, penetró el melancólico y pálido poeta" P... L... de G..., quien tras dejarse caer en uno de aquellos sufridos divanes, suspiró, más que dijo, con aliento apenas perceptible:

-Camarero...

—¿Qué desea? -le contestó aquel en el mismo misterioso tono de voz.

-Tráigame un café con leche, susurró el desvencijado vate, siempre dentro del mismo clima- ¡pero que tenga mucho café y mucha leche!... Luego diré porqué...

Retiróse intrigadísimo el camarero, retornando a los pocos minutos con un verdadero jarro de humeante líquido, el que depositó sobre la mesa, al mismo tiempo que preguntaba, dentro del mayor misterio: ¿Por qué?

- ¡Porque me gusta con mucho azúcar! -clamó la voz cavernosa del poeta desfallecido ("Rehilete en el viento", Correo Literario, no 2, 1944: 4).

Pedro Luis de Gálvez, el poeta del hambre y la rebeldía, entró en la agonía por cuarta y no última vez de su vida. Rodeado de admiradores, el ácrata y ateo convencido asombró a sus amigos pidiendo con voz temblorosa "¡Un cura, por favor! ¡Confesión!”. Dudaron un instante, pero era la última (?) voluntad y había que respetarla. Llegó el sacerdote. Pasaron los amigos a la escalera, que otra habitación no había. Hubo un silencio lúgubre, hasta que de pronto se abrió violentamente la puerta de la estancia, de la que salió indignado el sacerdote exclamando: "Pero qué agonizante es este, que me ha pedido prestadas dos pesetas!" ("Rehilete en el viento", Correo Literario, no 4, 1944: 4).

Xunto a estas anécdotas apareceron moitas máis relacionadas, esencialmente, co mundo do teatro, dado que moitos dos desterrados que colabora- 
ban en Correo Literario tiveron gran relación cos ambientes teatrais da capital antes do estalido da guerra; tamén coas belas artes, pois Seoane e outras figuras chave na revista movíanse nas contornas artísticas. Todas elas, citadas ou non, esconden un nivel de veracidade que non podemos confirmar. Con respecto ás coetáneas, consideramos que puido haber algo ou moito de verdade; no obstante, daquelas de personaxes históricos anteriores, transmitidas de oídas, descoñecemos o seu alcance. Tal é o caso da seguinte, quizais escoitada e comentada na infancia e mocidade dos galegos, relacionada cun político compostelán falecido en 1914, dous anos antes do nacemento de Varela, cando Seoane tiña catro anos e Dieste cumprira quince:

Don Eugenio Montero Ríos, famoso abogado y político gallego a quien su astucia y dotes gubernativas hizo que se le conociera con el expresivo "alias" de "El zorro de Lourizán", gustaba de contar-siempre en tercera persona, claro está-, la siguiente anécdota abogaderil, suficiente a dejar tamañitos a los dickensianos Dodson y Fog.

-Cuenta mi esposa -comenzaba don Eugenio-, que, hace de esto ya bastantes años, la mujer de un leguleyo rural, oyó, mientras se dedicaba a los quehaceres hogareños los siguientes retazos de consulta pesetera.

- Mire señor doctor -decía una voz vernácula-, ayer mañana se me entró en el corral el caballo de Lirán... ¿Qué hago?

-Guarda el caballo... El caballo es tuyo.

Poco más tarde, la "otra parte" decía con acento no menos racial: me metió en el corral de Pepiño "El Americano"... ¿Qué hago?...

-Pleitea... El caballo es tuyo...

La atónita esposa, apenas hubo salido el segundo cliente le preguntó a su esposo. — ¿Cómo has podido decirles a los dos que el caballo es suyo?

— ¡Calla mujer! -afirmó con sonrisa indescriptible aquel Salomón de las Rías Bajas-. iiEl caballo es nuestro!! ("Rehilete en el viento”, Correo Literario, n 37, 1945: 4).

\section{Conclusión}

Por tanto, como vimos a través destes fragmentos inéditos, Lorenzo Varela foi moito máis que poeta, ensaísta, crítico ou editor. Nesta revista deu renda solta a unha faceta que iniciara con anterioridade noutra revista, De Mar a Mar, onde por primeira vez apareceron algúns dos seus textos máis acedos. Correo Literario proporcionoulle o espazo, a través de diferentes seccións, para desenvolver a súa vertente máis irónica. Así, contou cunha importante cantidade de colaboracións máis aló das referidas á arte ou á literatura, 
outras anónimas que ofreceron un carácter distinto e novo á publicación, as cales achegan moito máis á traxectoria deste intelectual.

"Nuevas" informaba de novidades literarias e dos camiños de moitos intelectuais durante a Segunda Guerra Mundial. Nesta sección, de forma anónima, tamén se procuraba poñer unha pequena pinga aceda que caía en cada páxina inicial co obxectivo de atraer os lectores.

"Carta abierta", como bo editorial, brillaba polo seu contido crítico, onde a sátira e a literatura tiveron moito que ver. Aquí non só a literatura e a cultura arxentina tiveron cabida, senón tamén marabillosas referencias a ese lugar de cuxo nome non puido deixar de acordarse.

Ademais incluíuse "Premáticas y desahogos", confirmando que o uso da escritura como desafogo era o seu selo distintivo. Nesta sección, de forma exclusiva e sen pretextos, vertía os seus pensamentos a través de sentenzas, comentarios ou anécdotas moi ligados ao contexto que facían o estilo de $\mathrm{Co}$ rreo Literario e Cabalgata único e distintivo.

Ao remate de cada número incluíase "Rehilete en el viento", onde se ofrecían divertidas anécdotas protagonizadas por personaxes históricos e do mundo cultural de todos os tempos e lugares. Nestas páxinas eran protagonistas o humor, a literatura e as outras artes, cambiando o ton amargamente irónico por outro máis amábel e divertido.

Así, tendo en conta o contexto cultural no que se editaba, onde a censura estaba moi presente, Correo Literario destacaba pola súa gran orixinalidade e valía. Non obstante, as dificultades e coartacións do momento levaron a Varela a deixar de participar en Cabalgata e mesmo a abandonar Arxentina durante un tempo.

Ana Martínez García

Universidade de Cádiz

\section{Bibliografía}

Ferreiro Fente, Gregorio. 2004. Homenaxe: Sesenta e seis escritores falan de Lorenzo Varela. Sada, A Coruña: Ediciós do Castro.

Ferreiro Fente, Gregorio. 2005. Diccionario Lorenzo Varela. A Coruña: TresCTres. 
Lopo, Antón. 2005. As tres mortes de Lorenzo Varela: biografía de un poeta. Lugo: Editorial Galaxia.

Pérez Rodríguez, María Antonia, López García, Xosé e Aneiros Díaz, Rosa (coords.). 2005. Lorenzo Varela en revistas culturais de México e Bos Aires: Taller, Romance, Letras de México, De Mar a Mar, Correo Literario, Cabalgata, Sur. Santiago de Compostela: Consello da Cultura Galega, http://consellodacultura.gal/mediateca/ documento.php?id=126 [Consulta: 15/11/2019].

Ramírez Sánchez, Mauricio César. 2010. "El muralismo mexicano y los artistas del exilio español”, en Crónicas, n ${ }^{\circ} 14$, http://www.revistas.unam.mx/index.php/ cronicas/article/view/24546 [Consulta: 21/08/2019].

Salgado, Daniel. 2005. "Premáticas y desahogos: palabra contra o derrumbamento", en Boletín da Real Academia Galega, n³ 366, pp. 49-61.

Salgado, Fernando. 2005. Lorenzo Varela. A voz desterrada. Sada-A Coruña: Ediciós do Castro.

Seoane, Luis. 1979. Lorenzo Varela. Homaxe. A Coruña: Ediciós do Castro.

Trapiello, Andrés. 2010. Las armas y las letras: literatura y guerra civil (1936-1939). Barcelona: Destino.

Zuleta, Emilia de. 1983. Relaciones literarias entre España y la Argentina. Madrid: Ediciones Cultura Hispánica de Instituto de Cooperación Iberoamericana.

VV.AA. (2005). Correo Literario [ed. facsímile]. Sada-A Coruña: Edicións do Castro. 